\title{
Pengaruh Latihan Small Sided Games 6 Vs 6 Dan 7 Vs 7 Terhadap Kecepatan, Kelincahan Dan Keterampilan Dribbling Pada Siswa Ekstrakurikuler Sepakbola SMPN 1 Pujut Lombok Tengah
}

\author{
Zakir Burhan \\ Institut Pendidikan Nusantara Global (IPNG) \\ Email: zakirburhan84@gmail.com
}

\begin{abstract}
Abstrak. Penelitian ini bertujuan untuk menguji pengaruh latihan small sided games 6 vs 6 dan 7 vs 7 terhadap kecepatan, kelincahan, dan keterampilan dribbling. Penelitian ini menggunakan pendekatan kuantitatif dengan jenis penelitian eksperimen semu (Quasi experimental design) dan menggunakan matching-only design. Subjek penelitian berjumlah 36 siswa. Metode pengumpulan data dalam penelitian ini menggunakan tiga instrumen penelitian, yaitu Tes kecepatan lari 40m untuk megukur kecepatan, Tes lari model $\mathrm{Z}$ untuk mengukur kelincahan, dan keterampilan dribbling. Sedangkan analisis data pada penelitian ini menggunakan analisis uji beda ( $t$-test) dan multivariat analisis of variance (MANOVA). Hasil dari penelitian ini terdapat peningkatan yang lebih signifikan pada kedua kelompok eksperimen dibandingkan dengan kelompok kontrol. Kecepatan terjadi peningkatan pada kedua kelompok eksperimen I dan II, tingkat kelincahan lebih terlihat pengaruhnya pada kelompok eksperimen I, sedangkan keterampilan dribbling terjadi peningkatan pada ketiga kelompok penelitian, baik kelompok ekperimen I, kelompok eksperimen II maupun kelompok ekspeimen III, namun berdasarkan dari hasil rerata yang tidak sama, hal ini menunjukankan variabel small sided games 6 vs 6 dan small sided games 7 vs 7 terbukti mampu berpengaruh terhadap ketiga variabel terikat akan tetapi relatif tidak sama, hal ini bisa disebabkan karena keterbatasan waktu yang ada dan minimnya pertemuan perlakuan perminggunya yang diberikan.
\end{abstract}

Kata Kunci: Small sided games 6 vs 6,7 vs 7, Kecepatan, Kelincahan, Keterampilan dribbling.

\section{PENDAHULUAN}

\section{Latar Belakang}

Sepakbola merupakan salah satu cabang olahraga yang sangat populer di dunia dan digemari oleh seluruh lapisan masyarakat, tidak terkecuali masyarakat di indonesia baik di kota maupun di desa. Sutanto (2016, p.17) mengungkapkan bahwa olahraga yang satu ini telah dimainkan oleh lebih dari 200 negara di dunia. Sepakbola dalam permainannya dimainkan dengan dua tim yang masing-masing dalam satu tim beranggotakan sebelas pemain dan lebih dikenal juga dengan sebutan kesebelasan, dalam permainannya olahraga sepakbola ini masing-masing kesebelasan saling berusaha untuk mencetak gol ke gawang lawan. Saat ini sepakbola telah menjadi olahraga industri dimana setiap klub sepakbola profesional memiliki banyak sponsor untuk meyediakan perelengkapan latihan sampai dengan seragam untuk pertandingan resmi. Suratman (2016, p.17) mengatakan bahwa olahraga sepakbola telah menjadi industri entertaiment dan gaya hidup masyarakat dunia.

Kondisi sepakbola nasional saat ini membutuhkan pembenahan dimulai dari yang paling dasar. Peningkatan prestasi sepakbola di Indonesia membutuhkan waktu yang cukup lama, serta dibutuhkan pembenahan yang serius di setiap aspeknya. Untuk mempunyai timnas yang kuat dan hebat serta berkualitas sepakbola Indonesia harus mengutamakan pembenahan pembinaan sepakbola diusia dini. Dalam mempersiapkan pemain profesional tidak akan bisa didapatkan dengan cara yang instan, dibutuhkan pembinaan dari usia muda yang baik dan benar sehingga pada puncak usianya akan menjadi pemain yang benar-benar telah siap baik segi fisik, mental maupun tekhnik. Oleh karena itu apabila sepak bola Indonesia ingin mempunyai tim nasional sepakbola yang berkualitas maka yang paling utama yang harus mendapat perhatian serius adalah pembinaan usia muda yang dilakukan secara sistematis dan berkelanjutan.

Kecepatan merupakan salah satu komponen dasar yang diperlukan pada cabang sepakbola. Alberto (2011, p.477) Mengatakan kemampuan untuk melakukan tindakan dengan kecepatan tinggi saat pertandingan sepakbola merupakan prasyarat penting untuk partisipasi sukses dalam olahraga. Untuk itu kecepatan merupakan salah satu unsur dasar yang harus dilatihkan dalam upaya mendukung pencapaian prestasi pemain sepakbola.

Kelincahan Merupakan kemampuan tubuh atau bagian tubuh untuk mengubah arah gerakan 
secara mendadak dalam kecepatan yang tinggi. Hidayat (2014, p.45), mengatakan kelincahan berkaitan erat antara kecepatan dan kelentukan. Dalam olahraga misalnya permainan sepakbola yang dimainkan dengan lapangan yang lebar, memerlukan gerakan yang kompleks. Sebagai cabang olahraga yang arah datang dan perginya bola tidak teratur, maka kemampuan bergerak dengan mengontrol, berlari menjemput bola, melompat, berhenti tiba-tiba, ataupun menghin dari lawan sangat diperlukan. Hal ini menunjukkan bahwa permainan sepakbola memerlukan unsur-unsur kelincahan.

Keterampilan menggiring bola sangat penting dalam sepakbola untuk memungkinkan pemain mempertahankan bola pada saat berlari untuk melewati lawan-lawanya mencari ruang terbuka. Sering kali seorang pemain mempunyai pilihan untuk menendang bola tetapi tidak memiliki pilihan untuk menendang bola langsung ke gawang atau untuk melakukan umpan kerekan satu tim. Menurut Larkin, (dalam Rozy, 2012, p.2) dalam usaha untuk mempertahankan penguasaan bola, pemain harus mampu bergerak dengan bola sampai ada kesempatan untuk menendang langsung kegawang atau mengumpan bola kerekan satu tim.

Small sided games merupakan bentuk latihan sepakbola dimana aturan permainanya tidak mengikuti aturan sepakbola yang sesungguhnya, dari segi ukuran lapangan, durasi waktu hingga jumlah pemain dimodifikasi sesuai dengan kelompok umur. Benham, dkk, (2017, p.234) Small sided games atau permainan sisi kecil banyak digunakan untuk sekaligus meningkatkan kebugaran, keterampilan taktik, dan dinamika permainan. Jamshad \& Praveen (2017, p.450) Pertandingan untuk pemain berusia antara 9-13 tahun juga mempersiapkan dan bermain di domain SSG dan berkisar 6 vs 6 sampai 8 vs 8 mengandalkan area dan mengelola Tubuh dalm pertandingan sepakbola.

Berdasarkan pernyataan di atas dapat disimpulkan bahwa kecepatan, kelincahan dan keterampilan dribbling pada cabang sepakbola berkaitan dengan latihan small sided games 6 vs 6 dan latihan small sided games $7 v s$. Untuk itu peneliti melakukan penelitian yang berjudul "Pengaruh Latihan small sided games 6 vs 6 dan latihan small sided games 7 vs 7 Terhadap Kecepatan, Kelincahan dan Keterampilan dribbling Pada Siswa Ekstrakurikuler SMPN 1 Pujut Lombok Tengah".

\section{METODE PENELITIAN}

Penelitian ini menggunakan pendekatan kuantitatif dengan jenis penelitian eksperimen semu (Quasi experimental design). Penelitian eksperimen adalah penelitian yang dilakukan secara ketat untuk mengetahui sebab akibat diantara variabel, dimana penelitian ini pempunyai ciri utama yaitu adanya perlakuan (treatment) yang diberikan pada subjek atau objek penelitian (Maksum, 2012, p. 65). Desain yang digunakan dalam penelitian ini yaitu peneliti menggunakan desain penelitian Matching Design (Maksum, 2012, p. 100). Desain penelitian dapat digambarkan sebagai berikut:

\begin{tabular}{|c|c|c|c|}
\hline \multirow{3}{*}{$\mathrm{M}$} & $\mathrm{T} 1 \mathrm{a}$ & $\mathrm{X} 1$ & $\mathrm{~T} 2 \mathrm{a}$ \\
\cline { 2 - 4 } & $\mathrm{T} 1 \mathrm{~b}$ & $\mathrm{X} 2$ & $\mathrm{~T} 2 \mathrm{~b}$ \\
\cline { 2 - 4 } & $\mathrm{T} 1 \mathrm{c}$ & $\mathrm{X} 0$ & $\mathrm{~T} 2 \mathrm{c}$ \\
\hline
\end{tabular}

Keterangan:

M : Matching

T1a : Kelompok 1 Pretest tes kecepatan, tes kelincahan dan tes keterampilan dribbling.

T1b : Kelompok 2 Pretest tes kecepatan, tes kelincahan dan tes keterampilan dribbling.

T1c : Kelompok 3 Pretest tes kecepatan, tes kelincahan dan tes keterampilan dribbling.

$\mathrm{X} 1$ : Metode latihan kelompok 1 small sided games 6 vs 6

X2 : Metode latihan kelompok 2 small sided games 7 vs 7

$\mathrm{X} 0$ : Latihan Konvensional

T2a : Kelompok 1 Posttest tes kecepatan, tes kelincahan dan tes keterampilan dribbling.

T2b : Kelompok 2 Posttest tes kecepatan, tes kelincahan dan tes keterampilan dribbling.

T2c : Kelompok 3 Posttest tes kecepatan, tes kelincahan dan tes keterampilan dribbling.

Populasi adalah keseluruhan subjek penelitian (Arikunto, 2013, p. 173). Populasi dalam penelitian ini seluruh pemain/siswa ekstrakurikuler sepakbola SMPN 1 Pujut lombok tengah, dengan total keseluruhan berjumlah 36 orang. Sampel adalah contoh subjek penelitian yang dicuplik dari populasi yang jumlahnya ditentukan dengan teknik tertentu (Sriundy, 2015, 
p.206). Jumlah sampel dalam penelitian ini yaitu sebanyak 36 subjek penelitian.

\section{Analisis}

Analisa data dalam penelitian menggunakan program SPSS 20.0 dengan taraf signifikan $5 \%$. Dilanjutkan pada uji prasyarat yang terdiri dari uji normalitas dan uji homogenitas. Pengujian normalitas dilakukan untuk mengetahui normal tidaknya suatu distribusi data. Hal ini penting diketahui berkaitan dengan ketetapatan pemilihan uji statistik yang akan digunakan. Uji homogenitas digunakan untuk mengetahui apakah dua atau lebih varian populasi adalah sama atau tidak.

Setelah uji prasyarat terpenuhi maka dilanjutkan dengan pengujian hipotesis. Untuk menguji hipotesis penelitian menggunakan teknik stastistik paired $t$ test dan multivariate analisis varians (Manova). Dengan menggunakan program SPSS 20.0.

\section{HASIL DAN PEMBAHASAN}

a. Uji Normalitas Data

Uji normalitas data menggunakan uji Kolmogorov smirnov dengan taraf signifikan 5\%. Uji homogenitas kovarian dilakukan untuk mengetahui homogen atau tidaknya data yang terkumpul. Uji homogenitas bertujuan untuk memastikan bahwa varian dari setiap kelompok sama atau sejenis, sehingga perbandingan dapat dilakukan secara adil (Maksum, 2012, p.162). Dalam penelitian ini digunakan lavene's test. Apabila nilai statistik lavine lebih besar dari 0.05 maka data memiliki varian yang homogen.

Tabel 1. Uji Normalitas Data

\begin{tabular}{|l|l|l|l|l|l|l|}
\hline \multirow{2}{*}{ Variabel } & \multirow{2}{*}{ Test } & Kel. I & Kel. II & Kel. III & \multirow{2}{*}{ Ket } & \multirow{2}{*}{ Status } \\
\cline { 3 - 7 } & & Sig & Sig & Sig & & \\
\hline Kecepatan & Pretest & 0,065 & 0,055 & 0,200 & $p>0.05$ & Normal \\
\cline { 2 - 7 } & Posttest & 0,115 & 0,068 & 0,200 & $p>0.05$ & Normal \\
\hline Kelincahan & Pretest & 0,200 & 0,200 & 0,200 & $p>0.05$ & Normal \\
\cline { 2 - 7 } & Posttest & 0,071 & 0,056 & 0,200 & $p>0.05$ & Normal \\
\hline Keterampilan \\
dribbling & Pretest & 0,105 & 0,091 & 0,077 & $p>0.05$ & Normal \\
\cline { 2 - 7 } & Posttest & 0,051 & 0,200 & 0,200 & $p>0.05$ & Normal \\
\hline
\end{tabular}

Dari data pretes diatas dapat dilihat bahwa seluruh data adalah normal atau sig. > 0,05 karena seluruh data $>0,05$.

b. Uji Homogenitas

Uji homogenitas bertujuan untuk memastikan bahwa varian dari setiap kelmpok sama atau sejenis, sehingga perbandingan dapat dilakukan secara adil (Maksum, 2012, p. 162 ).

Tabel 2. Uji Homogenitas

\begin{tabular}{lllll}
\hline Variabel & Test & Sig $(\mathrm{P})$ & Ket & Status \\
\hline \multirow{2}{*}{ Kecepatan } & Pretest & 0,464 & $p>0,05$ & Homogen \\
\cline { 2 - 5 } & Posttest & 0,275 & $p>0,05$ & Homogen \\
\hline \multirow{2}{*}{ Kelincahan } & Pretest & 0,644 & $p>0,05$ & Homogen \\
\cline { 2 - 5 } & Posttest & 0,885 & $p>0,05$ & Homogen \\
\hline \multirow{2}{*}{$\begin{array}{l}\text { Keterampilan } \\
\text { dribbling }\end{array}$} & Pretest & 0,595 & $p>0,05$ & Homogen \\
\cline { 2 - 5 } & Posttest & 0,775 & $p>0,05$ & Homogen \\
\hline
\end{tabular}

Dari data diatas dapat dilihat bahwa seluruh data adalah homogen atau sig. > 0,05 karena seluruh data $>0,05$.

c. Uji Beda

Untuk menguji apakah terdapat pengaruh dari perlakuan (treatment) terhadap variabel yang digunakan maka dilakukan paired t test. Berikut ini akan dijabarkan hasil penelitian uji beda tiap kelompok.

Tabel 3. Hasil Uji Beda Variabel Kecapatan Paired Samples Test

\begin{tabular}{|c|c|c|c|c|c|}
\hline & & Mean & $\begin{array}{l}\text { Standar } \\
\text { Deviasi }\end{array}$ & $\mathrm{T}$ & $\begin{array}{c}\text { Sig. } \\
(2 \text {-tailed })\end{array}$ \\
\hline $\begin{array}{l}\text { Pair } \\
1\end{array}$ & $\begin{array}{l}\text { Pretest games } 6 \text { vs } 6 \text { Kecepatan - } \\
\text { Posttest games } 6 \text { vs } 6 \text { Kecepatan }\end{array}$ & -1.933 & .799 & -9.374 & .000 \\
\hline pair 2 & $\begin{array}{l}\text { Pretest games } 7 \text { vs } 7 \text { Kecepatan - } \\
\text { Posttest games } 7 \text { vs } 7 \text { Kecepatan }\end{array}$ & -3.067 & .884 & -13.44 & .000 \\
\hline pair 3 & $\begin{array}{l}\text { Pretest Kontrol Kecepatan- } \\
\text { Posttest Kontrol Kecepatan }\end{array}$ & -.333 & .900 & -1.435 & . 173 \\
\hline
\end{tabular}

Berdasarkan tabel 3 hasil perhitungan uji beda sampel berpasangan menggunakan uji-t paired $t$-test sebagai berikut :

1) Kelompok I (small sided games 6 vs 6 )

Hasil dari perhitungan uji-t paired t-test pada pemberian latihan small sided games 6 lawan 6 dengan melihat nilai Sig. (2-tailed) 0.000, maka dapat disimpulkan bahwa $\mathrm{H} 0$ ditolak dan Ha diterima karena nilai Sig. $0.000<$ nilai $\alpha=0,05$. Dengan kata lain terdapat pengaruh latihan yang signifikan dari pemberian latihan small sided games 6 vs 6 terhadap peningkatan kecepatan siswa ekstrakurikuler sepakbola SMPN 1 Pujut Lombok Tengah.

2) Kelompok II (small sided games 7 vs 7) Hasil dari perhitungan uji-t paired t-test pada pemberian latihan small sided games 7 vs 7 dengan melihat nilai Sig. (2-tailed) 0.000, maka dapat disimpulkan bahwa H0 ditolak dan Ha diterima karena Sig. $0.000<$ nilai $\alpha=0,05$. Dengan kata lain terdapat pengaruh latihan yang signifikan dari pemberian latihan small sided games 7 vs 7 terhadap peningkatan kecepatan siswa ekstrakurikuler sepakbola SMPN 1 Pujut Lombok Tengah.

3) Kelompok III ( Kontrol)

Hasil dari perhitungan uji-t paired t-test pada kelompok kontrol dengan melihat nilai Sig. (2-tailed) 0.173, maka dapat disimpulkan bahwa H0 diterima dan Ha ditolak karena 
nilai Sig. $0.000>$ nilai $\alpha=0,05$. Dengan kata lain tidak terdapat pengaruh signifikan peningkatan kecepatan siswa ekstrakurikuler sepakbola SMPN 1 Pujut Lombok Tengah.

Tabel 4. Hasil Uji Beda Tingkat Kelincahan Paired Samples Test

\begin{tabular}{llcccc}
\hline & Mean & $\begin{array}{c}\text { Standar } \\
\text { Deviasi }\end{array}$ & T & $\begin{array}{c}\text { Sig. } \\
\text { (2-tailed) }\end{array}$ \\
\hline Pair & $\begin{array}{l}\text { Pretest games 6 vs 6 Kelincahan - } \\
\text { Posttest games 6 vs 6 Kelincahan }\end{array}$ & 4,267 & 1,438 & 11,495 & 0,000 \\
\hline & $\begin{array}{l}\text { Pretest games 7 vs 7 Kelincahan - } \\
\text { pairttest games 7 vs 7 Kelincahan }\end{array}$ & 1,267 & 1,280 & 3,833 & 0,002 \\
\hline & $\begin{array}{l}\text { Pretest Kontrol Kelincahan - } \\
\text { Pair 3 }\end{array}$ &,- 200 & 0,414 & $-1,871$ & 0,082 \\
\hline
\end{tabular}

Berdasarkan tabel 4. hasil perhitungan uji

beda sampel berpasangan menggunakan uji-t paired $t$-test sebagai berikut :

1) Kelompok I (small sided games 6 vs 6 )

Hasil dari perhitungan uji-t paired t-test pada pemberian latihan small sided games 6 lawan 6 dengan melihat nilai Sig. (2-tailed) 0.000, maka dapat disimpulkan bahwa $\mathrm{H} 0$ ditolak dan Ha diterima karena nilai Sig. $0.000<$ nilai $\alpha=0,05$. Dengan kata lain terdapat pengaruh latihan yang signifikan dari pemberian latihan small sided games 6 vs 6 terhadap Tingkat Kelincahan siswa ekstrakurikuler sepakbola SMPN 1 Pujut Lombok Tengah.

2) Kelompok II (small sided games 7 vs 7 )

Hasil dari perhitungan uji-t paired t-test pada pemberian latihan small sided games 7 vs 7 dengan melihat nilai Sig. (2-tailed) 0.002, maka dapat disimpulkan bahwa H0 ditolak dan Ha diterima karena Sig. $0.000<$ nilai $\alpha=$ 0,05. Dengan kata lain terdapat pengaruh latihan yang signifikan dari pemberian latihan small sided games 7 vs 7 terhadap tingkat Kelincahan siswa ekstrakurikuler sepakbola SMPN 1 Pujut Lombok Tengah.

3) Kelompok III ( Kontrol)

Hasil dari perhitungan uji-t paired t-test pada pemberian latihan kelompok kontrol dengan melihat nilai Sig. (2-tailed) 0.082, maka dapat disimpulkan bahwa H0 diterima dan Ha ditolak karena nilai Sig. $0.000>$ nilai $\alpha=$ 0,05 . Dengan kata lain tidak terdapat pengaruh signifikan tingkat Kelincahan siswa ekstrakurikuler sepakbola SMPN 1 Pujut Lombok Tengah.

Tabel 5. Tabel Uji Beda Keterampilan dribbling

\begin{tabular}{|c|c|c|c|c|c|}
\hline \multicolumn{6}{|c|}{ Paired Samples Test } \\
\hline & & Mean & $\begin{array}{l}\text { Standar } \\
\text { Deviasi }\end{array}$ & $\mathrm{T}$ & $\begin{array}{l}\text { Sig. } \\
\text { (2-tailed }\end{array}$ \\
\hline Pair 1 & $\begin{array}{l}\text { Pretest games } 6 \text { vs } 6 \text { Keterampialan- } \\
\text { Posttest games } 6 \text { vs } 6 \text { Keterampilan }\end{array}$ & $-5,600$ & 3,019 & $-7,184$ & 0,000 \\
\hline pair 2 & $\begin{array}{l}\text { Pretest games } 7 \text { vs } 7 \text { Keterampilan - } \\
\text { Posttest games } 7 \text { vs } 7 \text { Keterampilan }\end{array}$ & $-6,133$ & 2,560 & $-9,280$ & 0,000 \\
\hline pair 3 & $\begin{array}{l}\text { Pretest Kontrol Keterampilan - } \\
\text { Posttest Kontrol Keterampilan }\end{array}$ & $-3,333$ & 1,345 & $-9,597$ & 0,000 \\
\hline
\end{tabular}

Berdasarkan table 5. hasil perhitungan uji beda sampel berpasangan menggunakan uji-t paired $t$-test sebagai berikut :

1) Kelompok I (small sided games 6 vs 6 )

Hasil dari perhitungan uji-t paired t-test pada pemberian latihan small sided games 6 lawan 6 dengan melihat nilai Sig. (2-tailed) 0.000 , maka dapat disimpulkan bahwa H0 ditolak dan Ha diterima karena nilai Sig. $0.000<$ nilai $\alpha=0,05$. Dengan kata lain terdapat pengaruh latihan yang signifikan dari pemberian latihan small sided games 6 vs 6 terhadap Keterampilan siswa ekstrakurikuler sepakbola SMPN 1 Pujut Lombok Tengah.

2) Kelompok II (small sided games 7 vs 7)

Hasil dari perhitungan uji-t paired t-test pada pemberian latihan small sided games 7 vs 7 dengan melihat nilai Sig. (2-tailed) 0.000, maka dapat disimpulkan bahwa HO ditolak dan Ha diterima karena Sig. $0.000<$ nilai $\alpha=$ 0,05 . Dengan kata lain terdapat pengaruh latihan yang signifikan dari pemberian latihan small sided games 7 vs 7 terhadap Keterampilan siswa ekstrakurikuler sepakbola SMPN 1 Pujut Lombok Tengah.

3) Kelompok III ( Kontrol)

Hasil dari perhitungan uji-t paired t-test pada pemberian latihan kelompok kontrol dengan melihat nilai Sig. (2-tailed) 0.000, maka dapat disimpulkan bahwa $\mathrm{HO}$ ditolak dan $\mathrm{Ha}$ diterima karena nilai Sig. $0.000<$ nilai $\alpha=$ 0,05 . Dengan kata lain terdapat pengaruh signifikan pada Keterampilan siswa ekstrakurikuler sepakbola SMPN 1 Pujut Lombok Tengah.

Tabel 6. Uji Beda Multivariat Tes

\begin{tabular}{|c|c|c|c|c|c|c|}
\hline Effect & & Value & $\mathrm{F}$ & Hypothesis df & Error $\mathrm{df}$ & Sig. \\
\hline \multirow[t]{4}{*}{ Intercept } & Pillai's Trace & 666 & $26,595^{\mathrm{b}}$ & 3,000 & 40,000 & ,000 \\
\hline & Wilks' Lambda & ,334 & $26,595^{\mathrm{b}}$ & 3,000 & 40,000 & ,000 \\
\hline & Hotelling's Trace & 1,994 & $26,595^{\mathrm{b}}$ & 3,000 & 40,000 &, 000 \\
\hline & Roy's Largest Root & 1,995 & $26,595^{\mathrm{b}}$ & 3,000 & 40,000 & ,000 \\
\hline \multirow[t]{4}{*}{ Kelompok } & Pillai's Trace & ,266 & 2,095 & 6,000 & 82,000 & ,063 \\
\hline & Wilks' Lambda &, 752 & $2,044^{\mathrm{b}}$ & 6,000 & 80,000 & ,069 \\
\hline & Hotelling's Trace & ,307 & 1,994 & 6,000 & 78,000 & ,077 \\
\hline & Roy's Largest Root & , 162 & $2,210^{\mathrm{c}}$ & 3,000 & 41,000 & 101 \\
\hline
\end{tabular}
perhitungan uji beda antar kelompok menggunakan Multivariat Analisis Of Variance, pada baris kelompok didapatkan nilai signifikan Wilks' Lambda sebesar 0,069. Maka dapat dikatakan nilai $P>0.05$. Sehingga berdasarkan nilai signifikan tersebut dapat disimpulkan bahwa tidak adanya perbedaan pengaruh antara variabel terikat kecepatan, kelincahan, dan keterampilan driblling secara bersama-sama. Oleh dari itu dapat dapat disimpulkan bahwa dari kedua metode latihan small sided games 6 vs 6 dan latihan small sided games 7 vs 7 tidak ada yang lebih efektif 
pengaruhnya terhadap kecepatan, kelincahan, dan keterampilan drriblling.

\section{KESIMPULAN}

Berdasarkan pada data yang dihasilkan latihan small sided games $6 \mathrm{vs} 6$ dan latihan small sided games 7 vs 7 dapat mempengaruhi dalam meningkatkan kecepatan, kelincahan, dan keterampilan driblling, walaupun jumlah dari hasil peningkatan tidak sama, dengan nilai t small sided games 6 vs 6 sebesar 0,000 dan small sided games 7 vs 7 sebesar 0,008 hal ini juga dapat dipengaruhi oleh padatnya kegiatan dari keseluruhan sampel yang kebetulan adalah siswa SMPN 1 Pujut Lombok Tengah.

\section{Ucapan Terima Kasih}

Di dalam melakukan penelitian ini terdapat banyak kekurangan dan tidak akan berhasil tanpa bantuan pihak-pihak yang terkait. oleh sebab itu terima kasih diucapkan kepada:

1. Bapak kepala SMPN 1 Pujut Lombok Tengah NTB.

2. Ibu dan bapak guru SMPN 1 Pujut khususnya pengampu mata pelajaran olahraga.

3. Seluruh siswa yang mengikuti ekstrakurikuler sepakbola SMPN 1 Pujut, yang terlibat.

\section{DAFTAR PUSTAKA}

Arikunto, S. 2013. "Prosedur Penelitian Suatu Pendekatan Praktik". Jakarta: Rineka Cipta

Soccer. Journal of Human Kinetics volume 57/2017, 129-137.

Bompa, Tudor O. Dan Buzzichelli, Carlo. 2015. Periodization Training for Sport. Edisi Ketiga. New York: Human Kinetics.

Bondarev, D.V. 2011. "Factors Influefing Cardiovascular Responses During Small Sided Games Performed with Recreational Purposes". Journal of Physical Education Ukraine, 2011, 2, 115-118.

Burhan, Z. 2019. Pengaruh Latihan 40-Yard Square-Carioca Dan Snake Jump Terhadap Kecepatan Dan Kelincahan Ekstrakurikuler Sepakbola.

Hidayat, S. 2014. Pelatihan Olahraga: Teori dan Metodologi. Yogyakarta. Graha Ilmu.
Hill-Haas, S.V; Dawson, B.; Impellizzeri, F.M. \& Coutts, A.J. 2011. "Physiology of Small-Sided Games Training in Football a Systematic Review". Journal of Sport Medicine, 2011; 41 (3): 199. 220.

Jamshad, M, \& Praveen, A. 2017. Effect of Small Sided Games on Selected Physical and Performence Related Variables Amoung Young Soccer Players. International Journal of Physical Education, Sport and Health 2017; 4(3):450-453.

Jones, S. \& Drust, B. 2007. "Physiological and Technical Demands of 4 vs 4 and $8 v 8$ Games in Elite Youth Soccer Players". Research Institute for Sports and Exercise, Liverpool John Moores University United Kingdom, 2,150-156.

Katis, A. \& Kellis, E. 2009. "Effects of SmallSided Games on Physical Conditioning and Performance in Young Soccer Players". Journal of Sport Science and Medicine, 2009, 8 374-380.

Maksum, A. 2012. Metodologi Penelitian dalam Olahraga. Surabaya: Unesa University Press.

Michael, J, Davies, Young, W, Farrow, D, \& Bahnert, H. 2013. Camparison of Agility Demands of Small-Sided Games in Elite Australian Football. International Journal of Sport Physiology and Performance, 2013, 8, 139-147. 2013 Human kinetics, Inc.

Rozy, A. 2012. "Pengaruh Pelatihan Small Sided Games 3 Lawan 3 dan 6 Lawan 6 Terhadap Kemampuan Dribling dan Passing Pemain Sepak Bola”. Tesis

Magister Pendidikan, Universitas Negeri Surabaya.

Snow, S dan Thomas, J. 2009. Small Side Games Manual. Coaching Education Depertement.

Sriundy, I Made Mahardika. 2015. Metodologi Penelitian. Surabaya: University Press. Sucharitha.

Sukadiyanto dan Muluk, N. 2011. Pengantar Teori dan Metodologi Melatih fisik. Bandung: Lubuk Agung.

Suratman, T. 2016. Strategi Olahraga Nasional Abad ke-21. Jakarta. PT Raja Grafindo Persada. 
Jurnal Ilmiah Mandala Education

http://ejournal.mandalanursa.org/index.php/JIME/index

Vol. 7. No. 3 Agustus 2021

Terakreditasi Peringkat 4 (No. SK: 36/E/KPT/2019)

Sutanto, T. 2016. Buku Pintar Olahraga.

Yogyakarta. Pustaka Baru Press 